637,313

F2s iv

1981

STATUS OF WHITE STURGEON IN

THE KOOTENAI RIVER

\title{
PLEASE RETURN
}

FATE DOCUMENTS COLZECTION

NOV 291983

MONTANA STATE LIBRARY

1515 E. 6th AVE.

FELENA, MONTANA 59620

\author{
BY \\ Patrick Graham \\ Montana Department of Fish, Wildlife and Parks \\ Kalispe11, Montana 59901 \\ January, 1981
}


3ye $810 \%$

\section{APR 171991}

JUL 8 - 1992

OCT 141992

SEP 82011
MONTANA STATE LIBRARY

S 639.313 F2mw $1981 \mathrm{c} .1$ Graham
Status of white gturgeon in the Kootenai

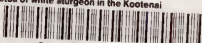

30864000461080
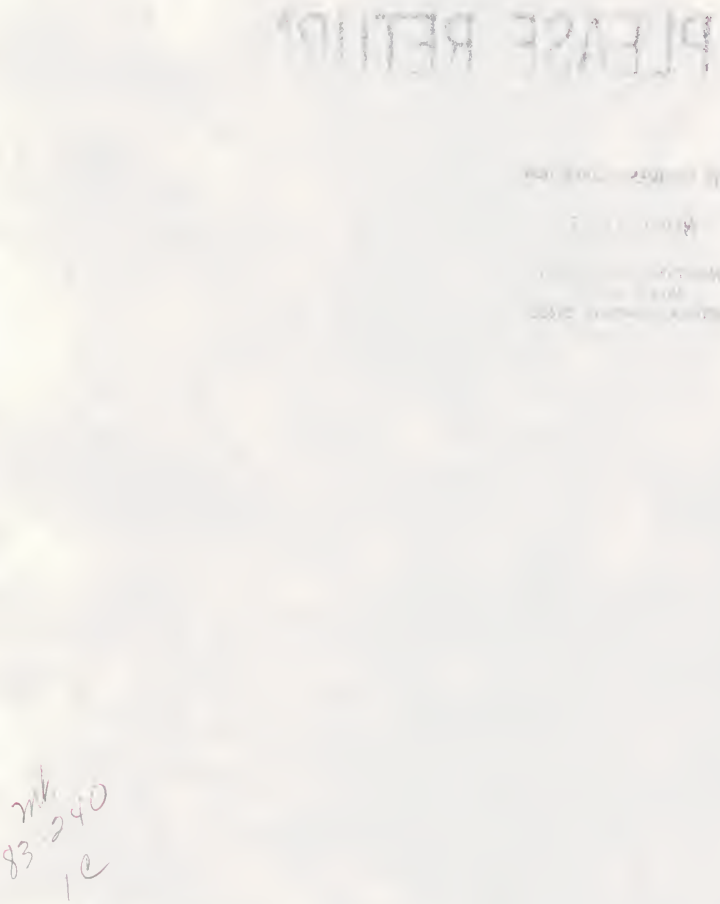


\section{ABSTRACT}

The white sturgeon (Acipenser transmontanus) is the largest freshwater fish in North America. In Montana, their distribution is limited to the Kootenai River downstream from Kootenai Falls. Although classified as a game fish, taking of white sturgeon has been prohibited since 1979. Indications of their diminishing numbers prompted this closure. Further investigations have led to the preparation of this report requesting classification of white sturgeon as endangered under the State of Montana Endangered Species Act, 1973.

Limited reports on the catch of white sturgeon in Montana ranged from five to 17 per year from 1968 to 1972. The sturgeon appear to migrate between British Columbia, Idaho and Montana. They probably moved upstream into Montana in late spring or early summer to spawn in the canyon areas below Kootenai Falls. Investigations in 1978 resulted in location and tagging of only three sturgeon, two of which were caught in Idaho. Only one sturgeon was observed by divers in 1980 and it had a tag in its back.

Conditions which probably contributed to the decline of white sturgeon in Montana include the operation of Libby Dam which was constructed in 1972 approximately 30 miles upstream from Kootenai Falls. Poor water quality in the Kootenai River in the 1950's and 1960's resulting from several mining operations upstream probably impacted the food supply of the sturgeon and possibly their reproduction.

No conclusive evidence is available on the cause for the decline in the sturgeon population. Rehabilitation efforts would have to include 1) evaluation of factors which trigger upstream migration of sturgeon and identifying the furthest upstream point in their spawning migration; 2) evaluation of 
present reproductive success of sturgeon and residual contaminants in fish tissues; and 3) reintroduction of sturgeon into the Kootenai River. These studies would require additional funding and cooperation with the Idaho Department of Fish and Game, British Columbia Fish and Wildlife Branch, U.S. Army Corps of Engineers, Bonneville Power Administration and other agencies which might be involved. 
LIST OF TABLES ................................. vi

LIST OF FIGURES. . . . . . . . . . . . . . . . . . vi vi

INTRODUCTION . . . . . . . . . . . . . . . . . . . . . . . . . 1

POPULATION EVALUATION . . . . . . . . . . . . . . . . . . 1

Distribution ...................... 1

Life History ............... . . . . . 3

Movement ................ 3

Reproduction ............... 5

Age and Growth............... 7

Food Habits ............... . . 9

POPULATION STATUS . . . . . . . . . . . . . . . . . . 9

Historical Abundance .............. . . 9

Present Status ................. . . 10

British Columbia ............. 10

Idaho ...................... 11

Montana .................... 11

FACTORS AFFECTING POPULATION ABUNDANCE ........... . . 15

Dam Related Factors............. . 15

Migration Barriers............. 15

Power Peaking . . . . . . . . . . . 16

Gas Supersaturation ............. . . 16

Pollution..................... 18

Exploitation ..................... 19

EXISTING CONSERVATION MEASURES . . . . . . . . . . . . . 21 
TABLE OF CONTENTS CONT.

ANTICIPATED FUTURE . . . . . . . . . . . . . . . . . . . . . . . . . . . . . 2122
Without Listing as an Endangered Species 22

RECOVERY PLAN . . . . . . . . . . . . . . . . 23

Problem Identification (Phase I) . . . . . . . . 23

Develop and Assess Recovery Alternatives (Phase II). . . . . 23 LITERATURE CITED ....................... 25 


\section{LIST OF TABLES}

Table

Page

1. Spawning requirements of several sturgeon species. (Adopted from White and Cochnauer 1975). . . . . . . . 6

2. Number of permits issued, percent returned, number caught and mean total length of white sturgeon in the Kootenay River upstream from Kootenay Lake in British Columbia from 1973-1980. (Data provided by Les Flech, B.C. Fish

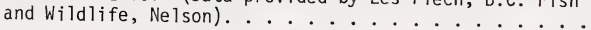

3. Records kept by anglers in the Kootenai River, below Kootenai Falls including number caught and kept and the mean and range of total fish length (Data provided by Vic

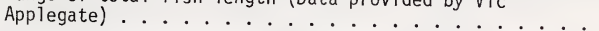

4. Selected water quality parameters of the St. Mary River upstream and downstream from effuents from the mine complex prior to $(1970$ - 74) and following (1976 - 77) effluent recycling. (Adopted from Malick 1978) 
Figures Page

1. Kootenai River drainage basin ........... 2

2. Length frequency of sturgeon tagged and released in the Kootenai River in Idaho and British Columbia from 1977 to 30 June 1980 and fish caught by Idaho anglers during 1979 (from Partridge, 1980) . . . . . . . . . . 8

3. Mean monthly discharge of the Kootenai River at Libby, Montana prior to impoundment (1970) and post impoundment (1977) ....................... 17 


\section{INTRODUCTION}

The status of white sturgeon (Acipenser transmontanus) in the Kootenai River from Kootenay Lakes, British Columbia to Kootenai Falls, Montana, is evaluated in this report with regard to the State of Montana "Nongame and Endangered Species Conservation Act." Endangered species means any species or subspecies of wildlife actively threatened with extinction due to any of the following factors: 1) the destruction, drastic modification, or severe curtailment of its habitat; 2) its overutilization for scientific, commercial, or sporting purposes; 3 ) the effect on it of disease, pollution or predation; 4) other natural or man-made factors affecting its prospects of survival or recruitment within the state; or 5) any combination of the foregoing factors. These factors are evaluated in respect to the status of white sturgeon. Recommendations are made for studies and actions necessary to improve the status of white sturgeon in Montana.

\section{POPULATION EVALUATION}

\section{DISTRIBUTION}

White sturgeon are anadromous in most of the large rivers in which they occur but are landlocked in the middle and upper Columbia River system. They are restricted to the Pacific shores of North America from Aleutian Islands of Alaska to Monterey, California (23).

In Montana, their natural distribution is restricted to 21.5 miles of the Kootenai River from Kootenai Falls to the Idaho-Montana border (Figure 1). In 1976, five white sturgeon were captured downstream from Kootenai Falls and released in Libby Reservoir which is about 27 miles 


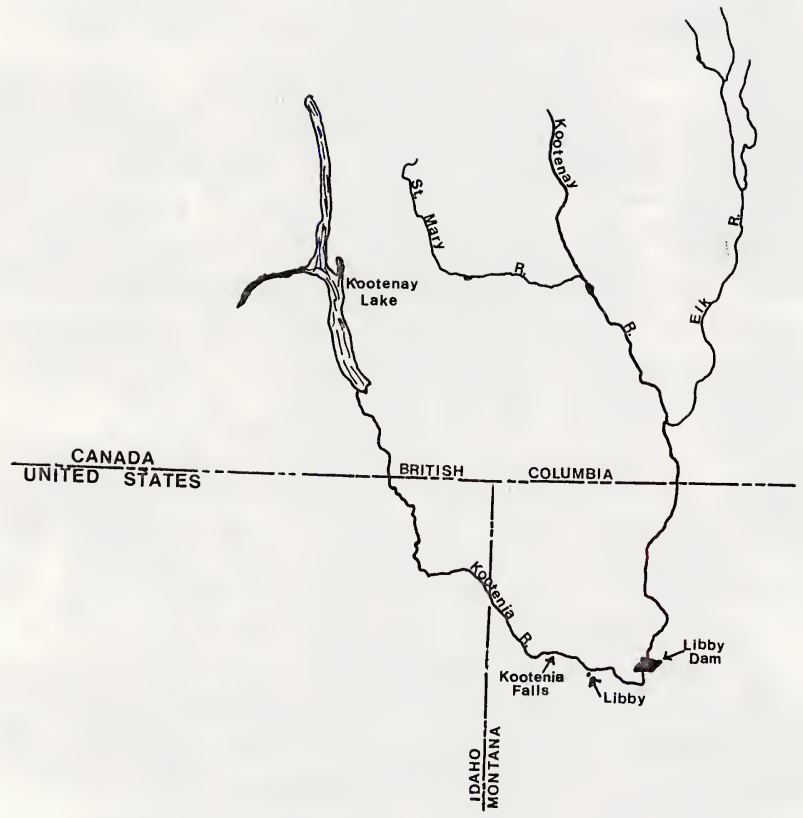

Figure 1. Kootenai River drainage basin. 
upstream from Kootenai Falls.

The Kootenai River flows downstream through Idaho for 66 miles. It crosses the Idaho border into British Columbia and flows 29 miles to Kootenay Lake. The white sturgeon are found throughout this portion of the Kootenai River and downstream to Kootenay Lake.

\section{LIFE HISTORY}

White sturgeon are the largest freshwater sport fish in North America, with the largest sturgeon purported to be 1800 pounds and caught in the Fraser River near New Westminster, British Columbia in 1897 (23).

Both anadromous and landlocked forms of white sturgeon exist. In freshwater, they prefer large, cold rivers. Little information has been collected on the life history of sturgeon in the Kootenai River. However, some data is available on white sturgeon in the lower Columbia, Snake, Fraser and Sacramento river systems (7, 12, 14, 15, 17, 18, 24).

\section{Movement}

Movement of sturgeon seems to vary between systems but all studies have documented some movement. In the middle Columbia River adult fish moved upstream in late spring and early summer and a few moved back downstream in late summer and early fall (12). The upstream movement was presumably a spawning migration.

In the mid-Columbia River small sturgeon moved downstream in summer and intermediate-sized sturgeon remained near release points (12). Movement ceased from mid-0ctober to May. In the Snake River small sturgeon (1ess then three feet in length) tended to move downstream, while movement of 
fish over six feet long was more localized (7). White sturgeon in the SacramentoSan Joaquin estuary remained in the estuary during summer, fall and early winter (18). They migrated upstream in late winter and spring, apparently on a spawning migration.

Efforts were made by a local fisherman to tag white sturgeon downstream from Kootenai Falls (2). The tags were ineffective and apparently pulled out of the fish. Four fish were caught with torn fins. Examination of the data suggests that at least two of these may have been caught in years following the year they were tagged in.

Latter efforts to assess movement of sturgeon in the Kootenai River system have found movement upstream from Kootenay Lakes into Idaho and downstream from Montana into Idaho. In 1978, personnel of the Montana Department of Fish, Wildlife and Parks caught and tagged three sturgeon downstream from Kootenai Falls (10). One of the fish had been tagged in 1976. Two of the three sturgeon were recaptured in the same location in 0ctober of 1978 . One had been captured previously on May 26 and again on July 14 . Both of these sturgeon were later captured downstream by an angler near Bonners Ferry, Idaho in the spring of 1980 (21).

Personnel from British Columbia have tagged sturgeon at the mouth of the Kootenai River on the south end of Kootenay Lake (1). Two of these fish were recaptured in Idaho, a distance of 58 and 61 miles $(93$ and 97 $\mathrm{km})$ upstream from their tagging location. Personnel from the Idaho Department of Fish and Game tagged a total of 136 sturgeon in the Kootenai River between November, 1977 and June, 1980 (20). Nine fish have been recaptured by Department personnel and anglers returned tags from three fish. 


\section{Reproduction}

Spawning period for white sturgeon occurs in May and June (23) although spawning in the Sacramento River occurred in March and April (14). Spawning probably occurs over rocky or bedrock substrate in swift current near rapids, when water temperatures are between 8.9 and $16.7 \mathrm{C}\left(48-62^{\circ} \mathrm{F}\right)(23)$.

Spawning criteria has been measured for several species of sturgeon (Table 1). Literature on other species of sturgeon report that they spawn in swift water at the foot of riffles or below a waterfall on rocky or bedrock substrate (27).

It is suspected that sturgeon spawn immediately below Bliss Dam on the Snake River in moderately fast water over bedrock substrate (6). I suspect that sturgeon spawn or use to spawn in the canyon below Kootenai Falls. The river bed is large bedrock mixed with large amounts of gravel, with fast current even at depth because the canyon is narrow and gradient is relatively steep.

Depth criteria for spawning of sturgeon native to rivers range from $5.0-16.4 \mathrm{ft} .(1.5-5.0 \mathrm{~m})$ and at velocities of $2.3-3.6 \mathrm{f} / \mathrm{s}(0.7-1.1$ $\mathrm{m} / \mathrm{s}$ ) (Table 1). Depths at which spawning occurs for lake sturgeon, a small adfluvial species, ranges from $2.0-15.0 \mathrm{ft}$. $(0.6-4.6 \mathrm{~m})$ :

A recommendation for minimum depth $\mathrm{cr}^{-}$teria for white sturgeon was set at $5 \mathrm{ft}$. $(1.5 \mathrm{~m})(27)$. The criteria was based on 1) criteria measured for other species; 2) the large size of mature white sturgeon; and 3) the fact that one female is accompanied by two or more males during the spawning act. A recommended range of velocities for spawning is $2.0-3.6 \mathrm{f} / \mathrm{s}(0.6-$ $1.1 \mathrm{~m} / \mathrm{s})(27)$.

Mature sturgeon survive spawning and return to spawn more than once, 
TABLE 1. Spawning Requirements of several sturgeon species. (Adopted from White and Cochnauer 1975).

\begin{tabular}{|c|c|c|c|c|c|c|c|}
\hline Sturgeon & $\begin{array}{l}\text { Literature } \\
\text { source }\end{array}$ & $\begin{array}{l}\text { Life } \\
\text { cycle }\end{array}$ & Temperature & Time & Depth & Velocity & Habitat \\
\hline White & 5,23 & An. & $\begin{array}{c}48-62 F \\
(8.9-16.7 \quad C)\end{array}$ & $\begin{array}{l}\text { May- } \\
\text { June }\end{array}$ & & & $\begin{array}{l}\text { Rocky bottom; } \\
\text { swift current } \\
\text { near rapids }\end{array}$ \\
\hline Lake & 5,23 & Ad. & $\begin{array}{c}53.6-66.2 \mathrm{~F} \\
(12-19 \mathrm{C})\end{array}$ & $\begin{array}{l}\text { April- } \\
\text { June }\end{array}$ & $\begin{array}{c}2-15 \mathrm{ft} \\
(0.6-4.6 \mathrm{~m})\end{array}$ & & $\begin{array}{l}\text { Swift water; } \\
\text { often at foot } \\
\text { of falls }\end{array}$ \\
\hline Lake & 22 & & $\begin{array}{c}53-60 \mathrm{~F} \\
(11.7-15.6 \mathrm{C})\end{array}$ & $\begin{array}{l}\text { Apri1- } \\
\text { May }\end{array}$ & & & $\begin{array}{l}\text { Just under water } \\
\text { surface; outside } \\
\text { bends of river } \\
\text { banks, especially } \\
\text { in upwelling } \\
\text { current along } \\
\text { steep angle } \\
\text { riprap }\end{array}$ \\
\hline Atlantic & 5,23 & An. & $\begin{array}{c}56-64 F \\
(13.3-17.8 \mathrm{C})\end{array}$ & & & & $\begin{array}{l}\text { Assumed to spawn } \\
\text { in pools below } \\
\text { falls }\end{array}$ \\
\hline Shortnose & 23 & Ad. & & $\begin{array}{l}\text { Apri1- } \\
\text { June }\end{array}$ & & & $\begin{array}{l}\text { Middle reaches } \\
\text { of large tidal } \\
\text { rivers }\end{array}$ \\
\hline Sevryuga & 13 & $A n$. & 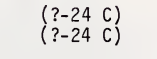 & $\begin{array}{l}\text { May- } \\
\text { June }\end{array}$ & $\begin{array}{c}13.1-16.4 \mathrm{ft} \\
(4-5 \mathrm{~m})\end{array}$ & $\begin{array}{l}2.3-3.6 \mathrm{fps} \\
(0.7-1.1 \mathrm{mps})\end{array}$ & $\begin{array}{l}\text { Gravel bars with } \\
\text { linear flow }\end{array}$ \\
\hline Sturgeon sp. & 25 & An. & $\begin{array}{c}49.1-E 4.4 \mathrm{~F} \\
9.6-18 \mathrm{C}\end{array}$ & $\begin{array}{l}\text { May- } \\
\text { June }\end{array}$ & $\begin{array}{l}4.9-6.6 \mathrm{ft} \\
(1.5-2 \mathrm{~m}) \\
\text { (eggs found) }\end{array}$ & High & \\
\hline
\end{tabular}

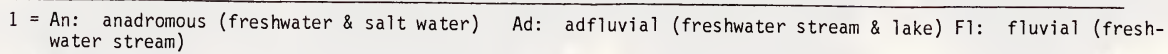


but only after several years. In the Fraser River, the time interval between repeat spawning was variable, occurring at intervals of $4-9$ years (24). Slower growth was exhibited in the years prior to spawning in males (for 2-5 years) and females 3-8 years). The interval increased each time spawning occurred beginning at four years in young females and up to 9 11 years in older females (23).

Age at maturity or first spawning is variable, occurring from 11 to 22 years of age for males and 26 to 34 years of age for females (24). Number of eggs per female increases with size ranging from 699,000 eggs in a female seven feet ten inches long to three to four million eggs weighing up to 250 pounds in large females (23).

White sturgeon are broadcast spawners and do not dig a nest. Their eggs are quite adhesive and the large, gray egg masses adhere to the rocks or bedrock on the stream bottom.

\section{Age and Growth}

Seven sturgeon captured below Kootenai Falls in 1975 and 1976 averaged 18 years of age and 39.3 in $(99.8 \mathrm{~cm})$ inches in length. The weighted average length of 19 sturgeon from 17 - 19 years of age was 43.4 inches $(110.1 \mathrm{~cm})$. The weighted average length of 9 sturgeon from 17 - 19 years of age in the Snake River was 112.9 inches (7). Of 129 sturgeon captured in British Columbia and 165 sturgeon captured in Idaho from 1977 to 1979 , only $11.2 \%$ (33) of these fish were less than 40 inches $(102 \mathrm{~cm}$ ) in length (20) (Figure 2). Sixtythree sturgeon caught in the Idaho portion of the river were aged. Only $11 \%$ (7) were less than 15 years of age. This is in contrast to the Snake River Study where 86\% (518) of the sturgeon aged were less Than 15 years old (7). Either the small sturgeon have not been located 

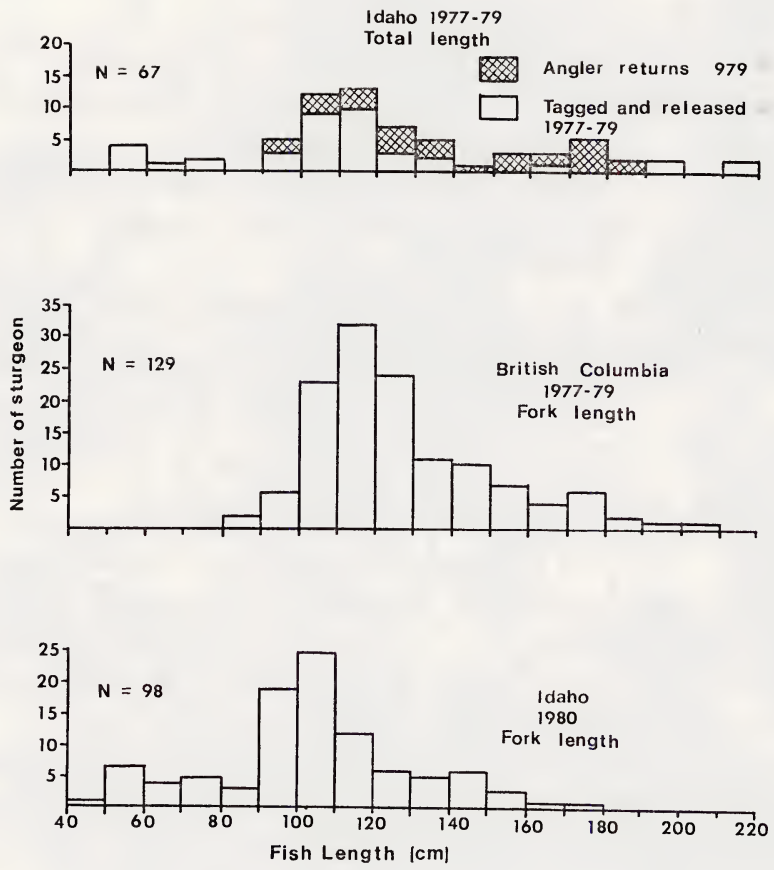

Figure 2. Length frequency of sturgeon tagged and released in the Kootenai River in Idaho and British Columbia from 1977 to 30 June 1980 and fish caught by Idaho anglers during 1979 (froil Partridge, 1980). 
or reproduction in the Kootenai River has been reduced since as early as 1965 .

\section{Food Habits}

White sturgeon are a botton feeder with a ventral, protrusible mouth for suction feeding. Ventral sensory barbles anterior to the mouth aid in locating food. Sturgeon are opportunistic and feed on a wide variety of items. Small sturgeon feed primarily on small aquatic insects like chironomid larvae. Their diet also includes clams, crayfish and Daphnia (23). Larger sturgeon become pisciverour feeding on live or dead fish including sculpins, three-spine stickleback, lampreys and other sturgeon $(23,24)$. Sturgeon in a laboratory tank rarely ate spoiled or fungused food or vegetable matter, but were observed eating small live fish held in the same tank (7).

\section{POPULATION STATUS}

\section{HISTORICAL ABUNDANCE}

Historical abundance of white sturgeon in the Kootenai River cannot be determined with accuracy. White sturgeon were utilized by Kootenai Indians at least several hundred years ago. Early explorers noted that canoes used by Kootenai Indians had a nose shaped like the head of a sturgeon.

More recently a fishery is known to have existed in the Kootenai River downstream from Kootenai Falls in Montana, Idaho and British Columbia. In the Montana portion of the Kootenai River, fishermen reported frequently catching sturgeon in the 1940's and 1950's on set-lines and while fishing for ling. The ling population rapidly declined in the late 1950's and 
early 1960's. This coincided with increased algal growth in the late 1950's and a subsequent decrease by the mid-1960's.

The catch of sturgeon during this period reportedly declined. Whether this was a result in a decrease in fishing pressure due to the small ling population or to an actual decrease in the number of sturgeon is not known. This is reviewed in a subsequent segment of this report (Factors Affecting Population Abundance: Pollution).

\section{PRESENT STATUS}

Estimates of the present abundance of white sturgeon have been obtained from a combination of sources including volunteer information by fishermen, recapture of marked sturgeon, angler interviews and sturgeon tags. No intensive studies have been conducted on white sturgeon in the Kootenai River.

Tagging of white sturgeon in British Columbia began in 1977, but population abundance and life history data is limited. A study was initiated in the Idaho portion of the Kootenai River in 1979. This was proceeded by two years of periodic tagging of sturgeon. The present study is funded by the U.S. Army Corps of Enginners (20). The study is directed at 1) assessing movement patterns; 2) identifying major use areas; and 3) determining the status of white sturgeon in the Idaho portion of the Kootenai River.

Studies in Montana have been limited to setting nets in 1975 and 1976 (16), nettin: and SCUBA diving from 1978 to 1980 (10), and fisherman logs of partial angler catch from 1968 through 1972 in the most popular fishing area in the Montana portion of the Kootenai River (2).

\section{British Columbia}

In British Columbia, anglers fish for sturgeon upstream from the 
delta of the Kootenai River at Kootenay Lake. A guess at the population size is up to several thousand, and it is believed they migrate upstream to Idaho and Montana to spawn (1). Sturgeon fishermen are required to secure a tag and return their catch information on an annual basis, although some illegal harvest is expected to occur. An average of 55 white sturgeon permits have been issued annually since 1973 (Table 2) (9). The annual harvest of legal and illegal fish is estimated to be between 10 and 20 sturgeon (1).

\section{Idaho}

An estimate of population size in Idaho is even more difficult because of fish movement. A rough estimate of 800 - 900 sturgeon was based on mark and recapture of sturgeon (21). Tag returns in Idaho included fish tagged in both British Columbia and Montana indicating that the sturgeon population uses the entire river. Based on contacts of permit holders, the legal harvest was estimated at 52 sturgeon, and an additional 341 sturgeon were caught and released (20). The illegal harvest is of course unknown, but is thought to be large, possibly equalling the legal harvest. Fishing pressure is apparently increasing because $57 \%$ of the fishermen contacted said it was their first year of sturgeon fishing (20).

\section{Montana}

The present population size in Montana is estimated to be from one to five sturgeon. Sturgeon fishing has been closed since 1979. The apparent stability of the sturgeon population in the British Columbia and Idaho portions of the Kootenai River suggest that few, if any, sturgeon migrate upstream into Montana and do not reside in Montana waters for extended periods of 
TABLE 2. Number of permits issued, percent returned, number caught and mean total length of white sturgeon in the Kootenay River upstream from Kootenay Lake in British Columbia from 1973-1980. (Data provided by Les Flech, B.C. Fish and Wildlife, Nelson).

\begin{tabular}{lccc}
\hline Year & $\begin{array}{c}\text { Number of } \\
\% \text { returned })\end{array}$ & $\begin{array}{c}\text { Number of } \\
\text { fish }\end{array}$ & $\begin{array}{c}\text { Tota 1 mean } \\
\text { 1ength (range)(in) }\end{array}$ \\
\hline 1973 & 35 & 7 & \\
1974 & $64(78)$ & 10 & \\
1975 & $76(53)$ & 17 & \\
1976 & $63(49)$ & 10 & $72(60-95)$ \\
1977 & $40(83)$ & 6 & $64(48-84)$ \\
1978 & $55(74)$ & 5 & $62.5(48-84)$ \\
1979 & $48(89)$ & 18 & \\
1980 & $56(79)$ & 8 & \\
\hline
\end{tabular}


time as they have in the past.

Vic Applegate, a Libby resident, recorded the catch of individuals that fished with him between June 1968 and May 1972. They caught 43 sturgeon of which 9 were killed (Table 3 ). This included the state record of 96 pounds captured by Herb Stout. Some of the sturgeon were probably caught more than once. Applegate began tagging sturgeon in August 1969 and tagged 13 over a three year period. No tags were observed on subsequent catches,although four fish had torn fins indicating tags may have pulled out.

Even the catches reported by Applegate are thought to be low compared to reports of sturgeon fisherman that catches were common in the $1940^{\prime} \mathrm{s}$ and 1950's. In 1975, biologists from the Montana Department of Fish, Wildlife and Parks captured and tagged only six sturgeon. Two more sturgeon were captured the following year. Five of these sturgeon were taken upstream and placed in Libby Reservoir in an effort to establish a population.

In 1978, numerous net sets, set-line fishing and rod and reel fishing produced only three sturgeon, all of which were captured at least twice (one of these sturgeon was tagged in 1976). Two of the sturgeon were captured downstream in Idaho by the same fisherman in the spring of 1980 .

Biologists searched about two miles of the canyon below Kootenai Falls in the summers of 1979 and 1980 using SCUBA gear and observed only one sturgeon each summer. The sturgeon observed in 1980 had a tag in its back, although no number could be observed.

The introduction of sturgeon into Libby Reservoir was probably not successful. Three of the sturgeon have been captured upstream from the reservoir in flowing-water habitat. It is also not known what their sex or state of maturity was. This was impossible to determine without sacrificing the fish. A discussion of further introductions is contained in the section 
TABLE 3. Records kept by anglers in the Kootenai River, below Kootenai Falls including number caught and kept and the mean and range of total fish length. (Data provided by Vic Applegate).

\begin{tabular}{lcc}
\hline Year & Number caught (kept) & Total mean length (in)(range) \\
\hline 1968 & $17(5)$ & $33(19-75)$ \\
1969 & $5(1)$ & $43.5(28-72)$ \\
1970 & 8 & $30.8(23-43)$ \\
1971 & $5(1)$ & $37.8(31-47)$ \\
1972 & $8(2)$ & $35.5(24-45)$ \\
\hline
\end{tabular}


"Population Recovery Alternatives".

FACTORS AFFECTING POPULATION ABUNDANCE

There has been a significant decline in the number of white sturgeon in the Montana portion of the Kootenai River where they were once common, at least seasonally. A direct link to the cause of their decline has not been determined due in part to several factors including; 1) paucity of life history data; 2) absence of long-term indicators of population size; and 3) poor understanding of factors which trigger upstream spawning migrations. Factors which may have contributed to the decline of white sturgeon in Montana are discussed.

DAM RELATED FACTORS

\section{Migration Barriers}

No conclusive evidence is available to indicate that sturgeon can migrate upstream and over Kootenai Falls. There are a few reports of people observing sturgeon upstream from the Falls. The most recent was a floater in 1980. He reported seeing a small fish near the town of Libby. It was laying in shallow water on a gravel bar. The unique characteristics described were those of a sturgeon. The estimated length would make it smaller than those fish transplanted into Libby Reservoir.

No dams presently impeed the movement of white sturgeon between Kootenay Lake and Kootenai Falls. Low stream flows from altered river discharge could create a natural barrier to migrating sturgeon, but none have sufficiently been documented to date. Construction of migration barriers downstream 
from Kootenai Falls would probably eliminate the movement of white sturgeon upstream from that point. Sturgeon do not utilize fishways at any of the Columbia or Snake River dams. They could use the boat locks, but apparently are not attracted to them (26).

\section{Power Peaking}

Fishermen in Idaho and Montana stated that fishing was best during the muddy, high water in late May and June. The construction of Libby Dam in 1972 completely altered the normal seasonal patterns of discharge. During the late spring when the river flows would naturally peak, the flows are low because Libby Dam is storing water (Figure 3). Natural high water during May and June averaged about $33,000 \mathrm{cfs}$, and now the flow is 3,000 to 5,000 cfs. Daily power peaking from the dam $(24,000 \mathrm{cfs})$ does not usually begin until July. Water temperatures in May and June are now $4-12^{\circ} \mathrm{F}$ cooler than prior to impoundment and sediment loads have been reduced by 90 percent.

The decline in white sturgeon numbers in Montana and the apparent stability of white sturgeon numbers in British Columbia and Idaho suggests that the spring spawning migration to Montana no longer occurs. Spawning migrations of stream fish are usually triggered by one or a combination of water temperature, discharge or photoperiod. of these factors, the major change in the river environment during the late spring was the reduced stream flow. Similar concerns have been reported in connection with a decline in sturgeon numbers in the Sacramento-San Joaquin river system (15).

\section{Gas Supersaturation}

Significant problems with gas supersaturation in the Kootenai River from 1972 through 1975 was a result from the use of sluices, and to a 


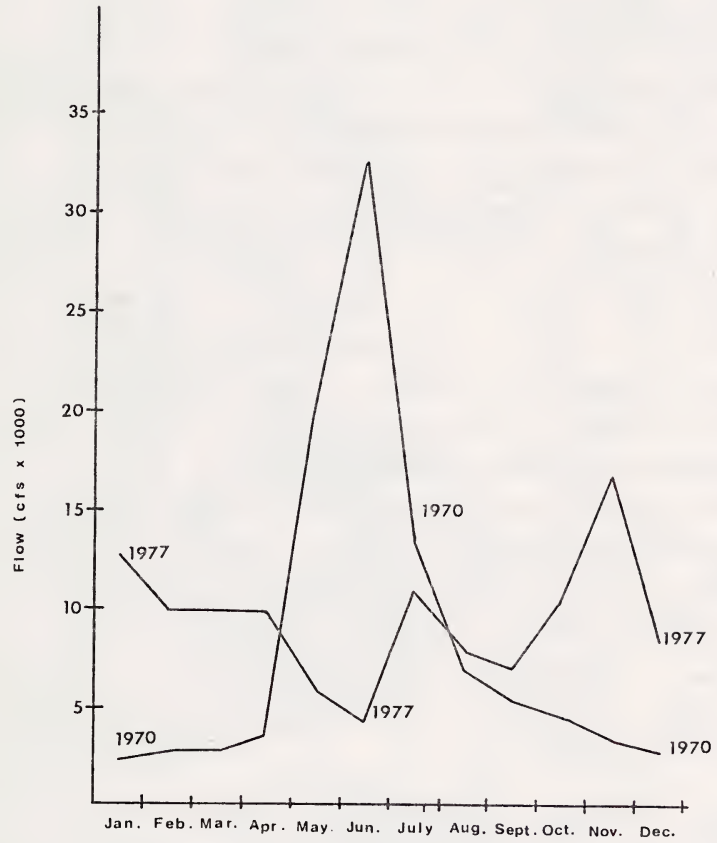

Figure 3. Mean montily discharge of the Kootenai River at Libby, Montana prior to impoundment (1970) and post impoundment (1977) 
lesser degree, spillways to discharge water from the dam. Gas supersaturation, when high, had marked effects on aquatic life in the Kootenai River causing flotation of insects clinging to gas bubbles resulting in increased downstream drift and susceptibility to predation.

It is not believed that these gas supersaturation problems caused significant damage downstream from Kootenai Falls (10). It is not known how the proposed Kootenai Falls Hydroelectric Project would affect gas saturation levels in the canyon below Kootenai Falls (11). It would be important to maintain gas saturation levels below 115\% if the Kootenai Falls project were constructed because dead or stunned fish and insects coming out of the return tunnel might concentrate white sturgeon in that area.

POLLUTION

In the 1950 's, a shift occurred in the fish population. Previously, there was a large abundance of cutthroat trout, burbot, a few rainbow trout and whitefish. The cutthroat and burbot decreased significantly and whitefish and rainbow trout increased. Fishermen noted that the water quality deteriorated during this time period resulting in increased algal growth, silt and sediments increased noticibly (4). Sediment loads during the spring appeared larger and more persistant and on occasion the river seemed to develope an odd color.

Major sources of pollution were industrial development on the St. Mary River in Canada and a Vermiculite mine and processing plant (W.R. Grace Company) upstream from Libby $(6.8$ miles). Turbid waters resulting from thickening and concentration of the vermiculite and drainage from the tailings caused water quality problems in the Kootenai River prior to 1971 (4). 
Pollution in the St. Mary River resulted from effluents from a lead-zinc mine, a concentrator, an associated fertilizer plant and city sewage plant (15). The mine began operation in 1900, the fertilizer plant in 1953 and the iron and steel plants operated from 1961 to 1972.

Water quality improved in 1968 following implementation of some waste water controls (4). Significant improvements in water quality were made in 1975 and 1977 largely by recycling effluents (15). Water quality samples in the St. Mary River in February 1968 had a ph of 3.8 , conductivity of 1,693 mohmn and total dissolved solids of $1,414 \mathrm{mg} / 1$. Water quality measurements in 1970 - 1974 had large concentrations of phosphorus and heavy metals (Table 4). Water quality problems also existed in the Elk River drainage as a result of coal mine operations.

The decline and shift in the fish population in the 1950's is undoubtedly the result of water quality problems. The poor water quality could have had two significant impacts on the white sturgeon. First, their food base could have been reduced, altered or both. Second, the heavy metals could have collected in the ovaries or eggs deposited in the river, reducing their rate of survival. This could have initiated the decline in the sturgeon utilizing the portion of the Kootenai River in Montana.

\section{EXPLOITATION}

Commercial exploitation of white sturyeon in the Columbia River resulted in a decrease in the harvest from 5.5 million pounds in 1892 to 73,000 pounds in 1899 (8). Early day exploitation probably removed the very large old sturgeon from the population. Present day limits restrict both the number and size of sturgeon that can be kept to protect both the young sturgeon and the older spawning fish. 
TABLE 4. Selected water quality parameters of the St. Mary River upstream and downstream from effuents from the mine complex prior to $(1970-74)$ and following $(1976-77)$ effluent recycling.

(Adopted from Malick 1978).

\begin{tabular}{|c|c|c|c|c|c|c|c|}
\hline \multicolumn{8}{|c|}{ PRE EFFLUENT RECYCLING } \\
\hline & $\mathrm{pH}$ & $\begin{array}{l}\text { Suspended } \\
\text { solids* }\end{array}$ & $\begin{array}{l}\text { Dissolved } \\
\text { phosphorus* }\end{array}$ & $\begin{array}{c}\text { Dissolved } \\
F^{\star}\end{array}$ & $\begin{array}{c}\text { Dissolved } \\
\mathrm{Zn}^{*}\end{array}$ & $\begin{array}{c}\text { Dissolved } \\
\mathrm{Pb}^{\star}\end{array}$ & $\begin{array}{c}\text { Dissolved } \\
\text { Fe* }^{*}\end{array}$ \\
\hline \multicolumn{8}{|l|}{$1970-1974$} \\
\hline Upstream & $6.8-7.5$ & $<40-50$ & $<0.005$ & $<0.15$ & 0.02 & $0.001-0.005$ & $<0.01$ \\
\hline Downstream & $3.5-7.5$ & $<100-270$ & $<2-9$ & $0-20$ & $0.05-0.6$ & $<0.02-0.12$ & $0.5-10$ \\
\hline
\end{tabular}

\section{POST EFFLUENT RECYCLING}

\begin{tabular}{|c|c|c|c|c|c|c|c|}
\hline & $\mathrm{pH}$ & $\begin{array}{c}\text { Suspended } \\
\text { solids* }\end{array}$ & $\begin{array}{l}\text { Dissolved } \\
\text { phosphorus* }\end{array}$ & $\begin{array}{c}\text { Dissolved } \\
F^{*}\end{array}$ & $\begin{array}{c}\text { Dissolved } \\
\mathrm{Zn}^{\star}\end{array}$ & $\begin{array}{c}\text { Dissolved } \\
\mathrm{Pb} *\end{array}$ & $\begin{array}{c}\text { Dissolved } \\
\mathrm{Fe}^{\star}\end{array}$ \\
\hline \multicolumn{8}{|l|}{$1976-1977$} \\
\hline Upstream & $6.0-7.9$ & $1-13$ & $<0.01-0.06$ & $<0.1-0.7$ & $<0.01-0.05$ & $<0.01-0.01$ & $<0.05-0.10$ \\
\hline Downstream & $6.3-7.9$ & $1-36$ & $0.01-0.66$ & $0.1-1.9$ & $0.02-0.36$ & $<0.01-0.01$ & $<0.05-0.50$ \\
\hline
\end{tabular}

*Expressed in $M G / L$ 
Regulations which apply to the Kootenai River in British Columbia require fishing by permit only, one sturgeon per year, larger than $100 \mathrm{~cm}$ in length, and by set-line only. In the Idaho portion, fishermen are allowed two fish per year, a minimum size of 36 inches in total length and a maximum size of 72 inches. Fishing for white sturgeon was terminated in 1979 in Montana. Prior to that, regulation included both a minimum and maximum size limit. Because of the lack of work done on the Kootenai River in Montana, and through the efforts of a concerned fisherman, the white sturgeon was only made a game fish in 1972.

\section{EXISTING CONSERVATION MEASURES}

Fishing for white sturgeon has been prohibited in Montana since 1979. No other specific conservation measures are known to exist.

\section{ANTICIPATED FUTURE}

\section{WITHOUT LISTING AS AN ENDANGERED SPECIES}

The limited information on white sturgeon in Montana would indicate they are very near extinction. Lack of adequate information on the life history and population changes in years past make it difficult to accurately identify the cause of their decline. Without further study, the feasibility and subsequent implementation of a recovery program would have questionable value.

An assessment of the feasibility of rehabilitating the sturgeon population without listing as an Endangered Species would require convincing 
potential funding sources and cooperators of our sincerity and concern for the white sturgeon. A recovery plan would entail the same alternatives with or without the proposed change in status and is contained in the section entitled "Population Recovery Alternatives".

\section{WITH LISTING AS ENDANGERED SPECIES}

The purpose of the state "Nongame and Endangered Species Conservation Act" of 1973 in regard to endangered species or subspecies indigenous to this state is to provide a means whereby the ecosystem upon which this species depends may be preserved and to provide a program for the conservation of the species to maintain or enhance its numbers.

The State is directed to assist in the protection of endangered wildlife by:

1) Prohibiting the taking, possession, transportation, exportation, processing, sale or offer for sale, or shipment within the state of endangered wildlife.

2) The director of the Department of Fish, Wildlife and Parks shall establish programs of land or aquatic habitat acquisition as are deemed necessary for management of endangered wildlife.

3) The department can enter into agreements with Federal agencies, political subdivisions of the State or with private persons for management of any area established for management of endangered wildlife.

Items 1 and 2 do not appear to offer significant opportunity for added protection of the white sturgeon at this time. Item 3 allows the department to negotiate with agencies such as the Corps of Engineers for the purpose of management of white sturgeon. Cooperative agreements with the Bonneville Power Administration, which controls flow regimes, would be reached under 
the new Pacific Northwest Power Planning and Conservation Act to fund studies to identify the problems and assess the feasibility of recovery of the population. Recovery will also depend on securing a supply of sturgeon or sturgeon eggs from other states.

\section{RECOVERY PLAN}

PROBLEM IDENTIFICATION (Phase I)

1) A more complete assessment of the spatial and temporal distribution of white sturgeon in the Kootenai River must be initiated in cooperation with Idaho and British Columbia to determine the present upstream limit of their spawning migration.

2. An assessment of the other fish and invertebrate populations downstream from Kootenai Falls to determine the available food source. Considerable work has been done upstream from the falls, but virtually none has been done downstream.

3) Model streamflow-temperature changes at Kootenai Falls and below the major tributaries downstream such as the Yaak and Moyie rivers to further evaluate moderating influence of major tributaries on the regulated flows resulting from Libby Dam.

4) Fish tissue analysis of white sturgeon for heavy metals in the Kootenai River. Studies in the Columbia River system (3) and the SacramentoSan Joaquin system (15) indicate PCB contamination of eggs may be causing problems with egg survival.

\section{DEVELOP AND ASSESS RECOVERY ALTERNATIVES (Phase II)}

These alternatives cannot be addressed specifically until the problem 
identification phase is completed. If regulated flows were the problem, the assessment would include: 1) determine potential for altering the existing flow regime; 2) assess impacts of flow alterations on other aquatic populations; and 3) determine impact of flow alterations on power production.

If a workable solution can be obtained, it might be necessary to secure a source of mature white sturgeon or eggs to begin a new run. Sturgeon hatcheries are non-existant, however, efforts are being made to incubate white sturgeon eggs in California to develop a population of sturgeon to supply caviar. This project is still in the early stages.

A potential egg supply may be the large sturgeon population downstream from Bonneville Dam in the Columbia River estuary. These fish do not migrate upstream in the Columbia anymore because of the numerous dams.

One possibility is to continue with the introduction of sturgeon into Libby Reservoir. This would have questionable value for Montana at this time. Studies in Idaho showed that white sturgeon moved upstream into flowing water habitat following impoundment of the Snake River (7). It is known that sturgeon are anadromous and young sturgeon move downstream into the ocean or some suitable large water body i.e. Kootenay Lake.

I speculate that sturgeon moved out of the Snake River reservoir because of the poor food supply. They are very large fish and probably forage a considerable amount of time. Like the Snake River Reservoir, Libby Reservoir undoubtedly has a poor food supply for the bottom-feeding sturgeon. It is likely that the sturgeon would move upstream out of the reservoir which backs up into Canada. To date, three of the five sturgeon put in Libby Reservoir have been caught. All three were caught in Canada, in flowingwater habitat (19). This alternative would be workable when and if Libby Reservoir developed a food base for sturgeon. 


\section{LITERATURE CITED}

1. Andrasak, J. 1980. Personal Communication. Idaho Department of Fish and Game, Bonners Ferry.

2. Applegate, V. 1971. The white sturgeon - a case for regulation. Mimeo report on file at Montana Fish and Game field station, Libby, MT. $8 \mathrm{pp}$.

3. Bosley, C. 1981. Personal Communication, U.S.F.W.S, Nordland, Washington.

4. Bonde, T.J.H. and R. M. Bush. 1975. Kootenai River water quality investigations - Libby Dam preimpoundment study. 1967-1972. Seattle District, Army Corps of Engineers.

5. Carlander, Kenneth D. 1969. Handbook of Freshwater Fishery Biology. Volume One. Iowa State University Press.

6. Cochnauer, T. 1980. Personal communication Idaho Department of Fish and Game, Jerome.

7. Coon, J.C., R.R. Ringe and T.C. Bjornn. 1977. Abundance, growth, distribution and movements of white sturgeon in the mid-Snake River. Idaho Water Resources Research Institute. Proj. B-026-IDA.

8. Galbreath, J. 1979. Columbia River Colossus - White Sturgeon. Oregon Wildlife. $34(3)$

9. Fleck, L. 1981. Personal communication. British Columbia Fish and Wildlife Branch, Nelson.

10. Graham, P.J. 1979. Aquatic Environmental Analys is of Kootenai Falls. Montana Department Fish, Wildlife and Parks. Prepared for Northern Lights Inc. and Department of Natural Resources and Conservation.

11. Graham, P.J. 1979. Kootenai Falls Aquatic Environment Study: Impact Study. Montana Department of Fish, Wildlife and Parks. Prepared for Northern Lights, Inc. and Department of Natural Resources and Conservation.

12. Haynes, J.M., R.H. Gray and J.C. Montgomery. 1978. Seasonal movements of white sturgeon (Acipenser transmontanus) in the mid-Columbia River. Trans. Amer. Fish. Soc. 107(2):275-280.

13. Khoroshko, P.N. and A.D. Vlasenko. 1970. Artifical Spawning Grounds of sturgeon. Journal of Ichthyology 10-(3): 286-292.

14. Kohlhorst, David W. 1976. Sturgeon spawning in the Sacramento River in 1973, as determined by distribution of larvae. California Fish and Game, $62(1): 32-40$. 
15. Malick, J.G. 1978. Changes in stream benthos in conjunction with upgrading wastes from a lead-zinc mine. B.C. Research, Vancouver. Presented at 26th Annual meeting of the North American Benthological Society.

16. May, B. and J.E. Huston. 1977. Kootenai River fisheries investigation March 1, 1976 through Apri1 30, 1977. Annual prog. report. Montana Department of Fish and Game.

17. McKechnie, Robert J. and R.B. Fenner. 1971. Food habits of white sturgeon, Acipenser transmontanus, in San Pablo and Suisun Bays, California. California Fish and Game 57(3):209-212.

18. Miller, Lee $W$. 1972. White sturgeon population characteristics in the Sacramento-San Joaquin Estuary as measured by tagging. California Fish and Game 58(2):94-101.

19. Oliver, G. 1980. Personal communication, British Columbia Fish and Wildlife Branch, Cranbrook.

20. Partridge, F. 1980. Kootenai River Fishery Investigations. Annual report. Contract DACW67-79-C-0133. Idaho Department of Fish and Game.

21. Partridge, F. 1980. Personal Communication. Idaho Department of Fish and Game, Bonners Ferry.

22. Priege1, Gordon R. and Thomas L. Wirth. 1971. The Lake Sturgeon: its life history, ecology and management. Publication 240-70. Wisconsin Department Natural Resources.

23. Scott, W.F. and E.J. Crossman. 1973. Freshwater Fishes of Canada. Bulletin 184, Fisheries Research Board of Canada.

24. Semakula, S.N. and P.A. Larkin. 1968. Age, growth, food and yield of the white sturgeon (Acipenser transmontanus) of the Fraser River, British Columbia. J. Fish. Res. Bd. of Canada 25(12):2589-2602.

25. Shilov, V.I. 1968. Breeding of sturgeon above the Volgograd Power Station in 1966. Journal of Ichthyology. 8(6):876-878.

26. Stockley, C. 1979. Personal communication. Washington Department of Fisheries, Vancouver.

27. White, R., and T. Cochnauer. 1975. Stream Resource Maintenance Flow Studies. Completion report to Idaho Fish and Game. 136 pp. 